\title{
Morphological and compositional variations of zircon and their metallogenetic implications: the example of the Jamon, Serra dos Carajás and Velho Guilherme suites, Amazonian Craton
}

\author{
Variação morfológica e composicional de zircão e suas implicações \\ metalogenéticas: o exemplo das suítes Jamon, serra dos Carajás e \\ Velho Guilherme, Cráton Amazônico
}

\author{
Claudio Nery Lamarão ${ }^{1,2 *}$, Joseanna dos Santos Silva², \\ Régis Munhoz Krás Borges ${ }^{1,2}$, Roberto Dall'Agnol ${ }^{1,2}$
}

\begin{abstract}
Zircon from granites of the Jamon suite (JS), Serra dos Carajás suite (SCS) and Velho Guilherme suite (VGS) were studied by scanning electron microscope (SEM) through backscattered electron and cathodoluminescence images and energy dispersive spectroscopy (EDS) analyses. Granites and greisens of the VGS have predominantly anhedral zircons that are altered and intensely corroded, are enriched in $\mathrm{Hf}$ and have the lowest $\mathrm{Zr} / \mathrm{Hf}$ ratios of the studied suites. In the granites, these ratios decrease towards the more evolved varieties. Zircons of the JS are euhedral to subhedral, zoned and slightly altered; they are also comparatively depleted in $\mathrm{Hf}$ and display the highest $\mathrm{Zr} / \mathrm{Hf}$ ratios, indicating limited potential for tin-associated mineralization. Zircons from granites of the SCS are subhedral to anhedral, altered and corroded, and show $\mathrm{Hf}$ contents and $\mathrm{Zr} / \mathrm{Hf}$ ratios intermediate to those of the JS and VGS. The granites of the VGS with Sn-, Ta- and W-associated mineralization contain zircons with $\mathrm{Zr} / \mathrm{Hf}$ ratios varying from 7 to 22 . It is concluded that ratios of similar magnitude can be used as a prospecting guide for specialized granites. Zircons from the greisens associated with the Cigano granite of the SCS have average $\mathrm{Zr} / \mathrm{Hf}$ ratios of approximately 23 , but no cassiterite was found in these rocks, indicating that the zircons preserved their magmatic geochemical signature. This study distinguished the three granitic suites in terms of zircon composition and demonstrated the importance of their geochemical signature, especially in terms of their $\mathrm{Zr} / \mathrm{Hf}$ ratio, in the identification of specialized granites. EDS-SEM analysis can thus be used in a preliminary assessment of the metallogenic potential of tin granites.
\end{abstract}

KEYWORDS: granitic suites; zircon; SEM techniques; cassiterite; $\mathrm{Zr} / \mathrm{Hf}$ ratio.
RESUMO: Zircóes de granitos das Suites Jamon (SJ), Serra dos Carajás (SSC) e Velho Guilherme (SVG) foram estudados em MEV por meio de imagens de elétrons retroespalhados e catodoluminescência e análises pontuais por EDS. Granitos e greisens da SVG apresentam zircóes dominantemente anédricos, alterados e intensamente corroídos, enriquecidos em $H f$ e com as mais baixas razöes $\mathrm{Zr} / \mathrm{Hf}$, as quais nos granitos tendem a decrescer no sentido das fácies mais evoluidas. Zircôes da SJ sáo euédricos a subédricos, zonados e pouco alterados, comparativamente empobrecidos em Hf e com as mais elevadas razóes $\mathrm{Zr} / \mathrm{Hf}$, indicando potencial reduzido para geração de mineralização estanifera. Zircóes dos granitos da SSC são subédricos a anédricos, alterados e corroídos e com conteúdos de Hf e razóes $\mathrm{Zr} / \mathrm{Hf}$ intermediárias a dos zircóes das SJ e SVG. Granitos da SVG com mineralizaçóes de Sn, We Ta apresentam zircóes com razóes $\mathrm{Zr} / \mathrm{Hf}$ entre 7 e 22. Conclui-se que razóes desta ordem podem ser utilizadas como guia prospectivo de granitos especializados. Por outro lado, zircôes de greisens associados ao Granito Cigano da SSC apresentaram razão Zr/Hf média em torno de 23, porém nenhuma cassiterita foi encontrada nessas rochas. Isto indica que estes zircóes preservaram sua assinatura magmática original. O estudo desenvolvido permitiu distinguir as três suites graníticas em termos de composição de zircão, e mostrou a importância da assinatura geoquímica desse mineral, sobretudo da razão $\mathrm{Zr} / \mathrm{Hf}$, na identificação de granitos especializados. Análises de zircōes por MEV-EDS podem, portanto, ser utilizadas na avaliação preliminar do potencial metalogenético de granitos estaníferos.

PALAVRAS-CHAVE: suites graniticas; zircão; análises de MEV; cassiterita; razão $\mathrm{Zr} / H f$.

\footnotetext{
${ }^{1}$ Grupo de Pesquisa Petrologia de Granitoides, Instituto de Geociências, Universidade Federal do Pará - UFPA, Belém (PA), Brazil. E-mail: lamarao@ufpa.br; munhoz@ufpa.br; robdal@ufpa.br

2Programa de Pós-Graduação em Geologia e Geoquímica, Instituto de Geociências, Universidade Federal do Pará - UFPA, Belém (PA), Brazil. E-mail: joseanna@ufpa.br ${ }^{*}$ Corresponding author
}

Manuscrito ID 30016. Recebido em: 24/07/2013. Aprovado em: 26/02/2014 


\section{INTRODUCTION}

Zircon is a mineral with a high chemical resistance that is often used in dating rocks, characterizing magmatic sources, determining the degree of magmatic fractionation and studying provenance. Zircon crystals often show great morphological and textural variation, which can aid in the understanding of their geological history and, by extension, that of their host rocks. Backscattered electron (BSE) and cathodoluminescence (CL) images obtained in a scanning electron microscope (SEM) stand out among techniques used to study these variations. BSE differentiates between mineral phases due to the variation of the atomic number of the elements that constitute the mineral and the variation in density contrast. The higher the atomic number of the element present in the sample, the clearer the final image. This type of image is very useful, particularly in studying zonation in accessory minerals (Krinsley \& Manley 1989; Paterson et al. 1989). CL is used as a petrological tool as certain minerals, including zircon, exhibit CL when bombarded with electrons. The use of these two techniques has allowed the identification of (1) distinct patterns of zoning, a feature typical of magmatic zircon and which indicate variations in the concentrations of $\mathrm{Zr}$, Si, Hf, Y, P, Th, U, REE, $\mathrm{Ca}$ and other elements present in the crystal structure of the zircon (Hanchar \& Miller 1993; Hanchar \& Hudnick 1995; Fowler et al. 2002); (2) inherited cores in magmatic zircons, which are surrounded by overgrowths (Paterson et al. 1992b; Vavra et al. 1996); (3) modifications caused during the later and/or post-magmatic stages such as an interruption of zoning, which can cause an appearance of patches and irregular edges enriched in certain components (e.g., $\mathrm{Hf}$ and $\mathrm{Ca}$ ) and (4) the presence of xenocryst inclusions (i.e., apatite or garnet) or mineral phases introduced after the formation of the zircon crystal (i.e., thorite, xenotime, cassiterite, monazite or fluorite). Punctual chemical analyses by SEM-EDS (energy dispersive spectroscopy) or electron microprobe are essential for the identification of compositional variations in zircons. However, it has been demonstrated that zircons of specialized granites have a significant enrichment of $\mathrm{Hf}, \mathrm{Y}$, Th, $\mathrm{U}$ and $\mathrm{Ca}$, and have low $\mathrm{Zr} / \mathrm{Hf}$ ratios, indicating that the composition of zircons can be a useful guide for the preliminary assessment of the metallogenic potential of tin-mineralized granites and associated metals (Wang et al. 2000; Kempe et al. 2004; Lamarão et al. 2007, 2010, 2012).

Three main Paleoproterozoic A-type granite suites with ages between 1.89 and $1.86 \mathrm{Ga}$ (Tab. 1), outcropping in the Carajás Province, Amazonian Craton, were individualized based on geological, petrochemical, geochronological and isotopic data (Dall'Agnol et al. 2005; Fig. 1): (1) Jamon suite (JS), located in the Rio Maria granite-greenstone terrain (RMGGT), represented by Jamon, Musa, Redenção, Bannach, Marajoara and Manda Saia plutons; (2) Serra dos Carajás suite (SCS) situated in the domains of the Carajás basin (CB), represented by Central, Cigano and Pojuca granites; (3) Velho Guilherme suite (VGS), occurring in the Xingu region (XR), formed by Antônio Vicente, Velho Guilherme, Mocambo, Serra da Queimada, Bom Jardim, Rio Xingu, Benedita, Ubim Norte and Ubim Sul granites (Teixeira et al. 2002, 2005; Lamarão et al. 2012).

This paper compares the morphological and compositional aspects of zircon crystals belonging to granitic bodies of the three above-mentioned suites. The data reported here were based on BSE-CL images obtained through a SEM and on semi-quantitative EDS minor element analyses. The aim is to demonstrate that these three suites can also be individualized by morphological and geochemical studies of their zircons and to highlight the efficiency of using the geochemical signature of this mineral as an indicator of tin-specialized granites and associated metals.

\section{GEOLOGICAL CONTEXT}

The three above-mentioned granite suites (Fig. 1) are located in the geochronological domain of the Central Amazonian Province (Tassinari \& Macambira 2004) with the JS and SCS in Carajás Province and the VGS in the Central Amazonian Province (Santos et al. 2000; Vasquez et al. 2008). The regions represented by the CB and the RMGGT are dominated by Archean rocks (Huhn et al. 1988; Macambira \& Lafon 1995; Souza et al. 2001; Leite et al. 2004; Dall'Agnol et al. 2006; Almeida et al. 2008; 2011; Vasquez et al. 2008; Oliveira et al. 2009a; Guimarães et al. 2010), which are partially hidden to the east by rocks of the Neoproterozoic Araguaia belt, whereas the XR is dominated by Paleoproterozoic volcanic and plutonic rocks with Archean Nd model ages (Teixeira et al. 2002; Vasquez et al. 2008; Juliani \& Fernandes 2010). The domains of the RMGGT, CB and XR were intruded by anorogenic granites with ages ranging from 1.89 to $1.86 \mathrm{Ga}$ (Tab. 1), which constitute the three investigated suites. Petrological, geochemical and isotopic studies (Dall'Agnol et al. 1999a, 2005; Rämö et al. 2002; Teixeira et al. 2002; Dall'Agnol \& Oliveira 2007; Oliveira et al. 2009b) show some contrasts between these granitic suites apart from the significant differences regarding their metallogenic potential. The most important deposits of gold, iron, copper, and manganese from Carajás Province are located in the $\mathrm{CB}$ region. In the XR, important deposits of cassiterite and wolframite are associated with granites of the VGS. In the RMGGT, 
small gold occurrences associated with greenstone belts and wolframite are linked with the JS (Dall'Agnol et al. 2005).

\section{PETROLOGICAL ASPECTS OF THE SUITES}

The three above-mentioned suites consist of granitic batholiths and stocks (Fig. 1) emplaced at shallow crustal levels and which commonly show sharp contacts and angular enclaves, suggesting a high viscosity contrast between magmas and Archean host rocks (Dall'Agnol et al. 2005; Oliveira et al. 2009a). The rocks are isotropic, equigranular or occasionally serial, ranging from fine to coarse grained. Monzogranites with subordinate syenogranites dominate the JS. The main accessory phases of the JS are apatite, titanite, zircon, allanite, magnetite and ilmenite. Fluorite appears only in the most evolved facies (Dall'Agnol et al. 1999a; Oliveira et al. 2009a). In the SCS, the principal rocks are monzogranites and syenogranites with moderate mafic mineral contents $(M<15 \%)$. The accessory phases are similar to those of the JS, but titanite is usually absent as a primary accessory and is more common as a product of biotite alteration; fluorite and topaz are more common and tourmaline appears locally (Barros et al. 1995; Rios et al. 1995; Villas 1999). In the VGS, syenogranites are more common than monzogranites, and alkali-feldspar granites and greisens mineralized in cassiterite and wolframite occur associated with more evolved rocks. Monazite, thorite, xenotime, fluorite and columbite are also common accessories (Teixeira et al. 2002; Lamarão et al. 2012). Magnetic susceptibility (MS) data show higher values for the plutons of the JS $\left(1.05 \times 10^{-3}\right.$ to $\left.54.73 \times 10^{-3}\right)$ and comparatively lower values for the dominant syenogranites of the Antônio Vicente granite of the VGS $\left(<1.0 \times 10^{-3}\right)$. The values of MS found in the SCS are more variable and generally intermediate between the former two $\left(1.0 \times 10^{-3}\right.$ to $5.0 \times 10^{-3}$; Dall'Agnol et al. 2005).

Table 1. Geochronological data from Paleoproterozoic suites of the Carajás region (modified from Dall'Agnol et al. 2005)

\begin{tabular}{|c|c|c|c|}
\hline Suite/Granite & Method of dating & Material & Age \\
\hline \multicolumn{4}{|l|}{ Jamon } \\
\hline Musa & $\mathrm{U}-\mathrm{Pb}$ & Zircon & $1883 \pm 5 \mathrm{Ma}^{(2)}$ \\
\hline Jamon & $\mathrm{Pb}-\mathrm{Pb}$ & Zircon & $1885 \pm 32 \mathrm{Ma}^{(3}$ \\
\hline Redenção & $\mathrm{Pb}-\mathrm{Pb}$ & Whole-rock & $1870 \pm 68 \mathrm{Ma}^{4}$ \\
\hline \multicolumn{4}{|l|}{ Serra dos Carajás } \\
\hline Cigano & $\mathrm{U}-\mathrm{Pb}$ & Zircon & $1883 \pm 2 \mathrm{Ma}^{(2)}$ \\
\hline Serra dos Carajás & $\mathrm{U}-\mathrm{Pb}$ & Zircon & $1880 \pm 2 \mathrm{Ma}^{(2)}$ \\
\hline Pojuca & $\mathrm{U}-\mathrm{Pb}$ & Zircon & $1874 \pm 2 \mathrm{Ma}^{(2)}$ \\
\hline \multicolumn{4}{|l|}{ Velho Guilherme } \\
\hline Velho Guilherme & $\mathrm{Pb}-\mathrm{Pb}$ & Whole-rock & $1874 \pm 30 \mathrm{Ma}^{15}$ \\
\hline \multirow[t]{2}{*}{ Rio Xingu } & $\mathrm{Pb}-\mathrm{Pb}$ & Zircon & $1866 \pm 3 \mathrm{Ma}^{(6)}$ \\
\hline & $\mathrm{Pb}-\mathrm{Pb}$ & Whole-rock & $1906 \pm 29 \mathrm{Ma}^{16}$ \\
\hline Mocambo & $\mathrm{Pb}-\mathrm{Pb}$ & Zircon & $1862 \pm 32 \mathrm{Ma}^{6}$ \\
\hline \multirow[t]{2}{*}{ Antonio Vicente } & $\mathrm{Pb}-\mathrm{Pb}$ & Zircon & $1867 \pm 4 \mathrm{Ma}^{(6)}$ \\
\hline & $\mathrm{Pb}-\mathrm{Pb}$ & Whole-rock +kf & $1896 \pm 9 \mathrm{Ma}^{(6)}$ \\
\hline Bom Jardim & $\mathrm{Pb}-\mathrm{Pb}$ & Zircon & $1867 \pm 1 \mathrm{Ma}^{(7)}$ \\
\hline Serra da Queimada & $\mathrm{Pb}-\mathrm{Pb}$ & Zircon & $1882 \pm 12 \mathrm{Ma}^{77}$ \\
\hline \multicolumn{4}{|c|}{ Other Paleoproterozoic granite } \\
\hline Seringa & $\mathrm{Pb}-\mathrm{Pb}$ & Zircon & $1895 \pm 1 \mathrm{Ma}^{(1)}$ \\
\hline
\end{tabular}

Data sources: (1) Paiva Júnior (2009); (2) Machado et al. (1991); (3) Dall'Agnol et al. (1999a); (4) Barbosa et al. (1995); (5) Macambira \& Lafon (1995); (6) Teixeira et al. (2002); (7) Pinho (2005). kf= alkali feldspar. 
According to Dall'Agnol et al. (2005), the three investigated suites exhibit geochemical characteristics of A-type granites, with $\mathrm{SiO}_{2}$ contents $>65 \mathrm{wt} . \%$ and $\mathrm{K}_{2} \mathrm{O} / \mathrm{Na}_{2} \mathrm{O}$ ratios typically between 1.0 and 2.0, with higher ratios towards JS - VGS - SCS. The rocks that constitute these suites are metaluminous to slightly peraluminous. Their $\mathrm{FeOt} /(\mathrm{MgO}$ $+\mathrm{FeOt}$ ) ratios are always higher than 0.80 and increase in the same direction of the $\mathrm{K}_{2} \mathrm{O} / \mathrm{Na}_{2} \mathrm{O}$ ratios and, within the same suite, increase from the less differentiated to the more evolved varieties. The patterns of rare earth elements show moderate to pronounced negative Eu anomalies, with a particularly striking 'seagull' pattern anomaly common in the tin-granites of the VGS and leucogranites of the SCS. TDM ages of the three suites vary significantly (from 3.35 to $2.60 \mathrm{Ga}$ ), whereas $\varepsilon \mathrm{Nd}$ values of the JS and SCS are similar (-10.5 to -8.1 and -9.7 to -7.9 , respectively) and higher than those of the VGS (-12.1 to -12.2), with the exception of the Mocambo granite (-7.9). Despite these variations, the values are consistent with derivation of the forming magmas from an Archean crustal source (Rämö et al. 2002).

\section{MORPHOLOGICAL AND COMPOSITIONAL STUDY OF ZIRCONS FROM PALEOPROTEROZOIC GRANITE SUITES}

\section{Analytical procedures}

Zircons from the three Paleoproterozoic granite suites were analyzed through the scanning electron microscope (LEO-1430; Geosciences Institute, Federal University of Pará, Brazil). Polished sections of selected samples were coated with carbon before BSE and EDS analyses. For CL images they were coated with gold for $30 \mathrm{~s}$. Operating conditions were as follows: accelerating voltage $=20 \mathrm{kV}$, beam current $=$ $90 \mu \mathrm{A}$, work distance $=15 \mathrm{~mm}$, analysis time $=30 \mathrm{~s}$ with 4,000 - 5,000 cycles/s for each analysis. The elements analyzed were O, Si, Zr, Hf, Ce, Nb, Ta, P, Y, Th, U, Ba and Ca. A total of 3,490 analyses were performed on the rims and cores of the zircon grains, and fractures and inclusions were avoided with the aid of the BSE and CL images. Ce, $\mathrm{P}$ and $\mathrm{Ba}$ contents were consistently very low and so were excluded from Tab. 2. The analyzed zircons were selected from the Jamon and Redenção plutons of the JS; the Central, Cigano and Pojuca plutons of the SCS; and the tin-granites of the Antônio Vicente, Bom Jardim, Mocambo, Serra da Queimada and Velho Guilherme plutons of the VGS. Zircons were selected from each of the different facies of each body, from the least to the most evolved and, in some cases, from samples of the associated greisens.

\section{RESULTS}

Table 2 presents the average chemical composition from zircon crystals of granites and associated greisens. A total of 3,490 EDS analyses were performed, including 571 zircon analyses from the JS, 1,565 from the SCS and 1,354 from the VGS.

\section{JAMON SUITE}

Jamon and Redenção granites have predominantly subhedral to euhedral zoned zircons, which are locally fractured and free of corrosion. Inclusions of apatite are common (Fig. 2). The mean contents of $\mathrm{Hf}$ are relatively low and show little variability (1.9 -2.3 wt.\%), even in the leucogranites of the Redenção pluton (2.2 wt.\%), producing $\mathrm{Zr} / \mathrm{Hf}$ ratios between 24 and 29 (Tab. 2). The average contents of $Y$ are lower than $1.0 \mathrm{wt} . \%$, except for the zircons of Redenção leucogranite, which presented a mean Y content of 1.5 wt.\%, producing $\mathrm{Zr} / \mathrm{Y}$ ratios between 64 and 81 for the first case and that of approximately 56 for the second. The $\mathrm{Nb}$ content in these zircons has a mean value of 1.2 and $0.2 \mathrm{wt} . \%$ to Th and $\mathrm{U}$, respectively. The sum of $\mathrm{Hf}+\mathrm{Y}+$ Th + U ranged from 4.2 and 3.0 wt.\%, with the Redenção leucogranite presenting higher average contents (Tab. 2).

\section{SERRA DOS CARAJÁS SUITE}

Zircons of the SCS from Central, Cigano and Pojuca granites are morphologically and compositionally distinct from those of the JS (Fig. 3, Tab. 2). Subhedral to anhedral crystals dominate and are often fractured and corroded, assuming sieve aspect. Alterations in the form of irregular patches, usually with high $\mathrm{Ca}$ contents, and thorite inclusions are observed in many crystals (Fig. 3). Anhedral crystals of thorite $(\leq 50 \mu \mathrm{m})$ associated with zircons are common in greisens of the Cigano granite (Fig. 3F). Compositionally, zircons of the SCS showed average Hf contents (3.1 wt.\%) higher than those of the JS (2.1 wt.\%), resulting in comparatively lower $\mathrm{Zr} / \mathrm{Hf}$ average ratios (19.0 for the JS and 26.0 for the SCS). Zircons from biotite monzogranite, biotite leucogranite and syenogranite of the Pojuca pluton showed the highest concentrations of Hf (2.7 - $5.8 \mathrm{wt} . \%)$ and the lowest $\mathrm{Zr} / \mathrm{Hf}$ ratios (20.5 to 7.6). With the exception of the leucogranite of the Redenção pluton, the $\mathrm{Y}$ contents in the zircons of the SCS are generally slightly higher than those of the JS (averaging 1.1 wt.\% in the SCS and 0.9 wt.\% in the JS). However, higher contents of this element were found in zircons from Pojuca leucogranites (1.6 wt.\%), yielding a $\mathrm{Zr} / \mathrm{Y}$ average ratio lower than that of the rocks of the JS (63.0 versus 70.0 wt.\%). The contents of $U$ and Th are also slightly higher in the zircons from the SCS, yielding values of $\mathrm{Hf}+\mathrm{Y}+\mathrm{U}$ + Th between 3.5 and 8.6 wt.\% (Tab. 2), which is generally higher than the maximum value obtained from zircons of the JS (4.2 wt.\%). 


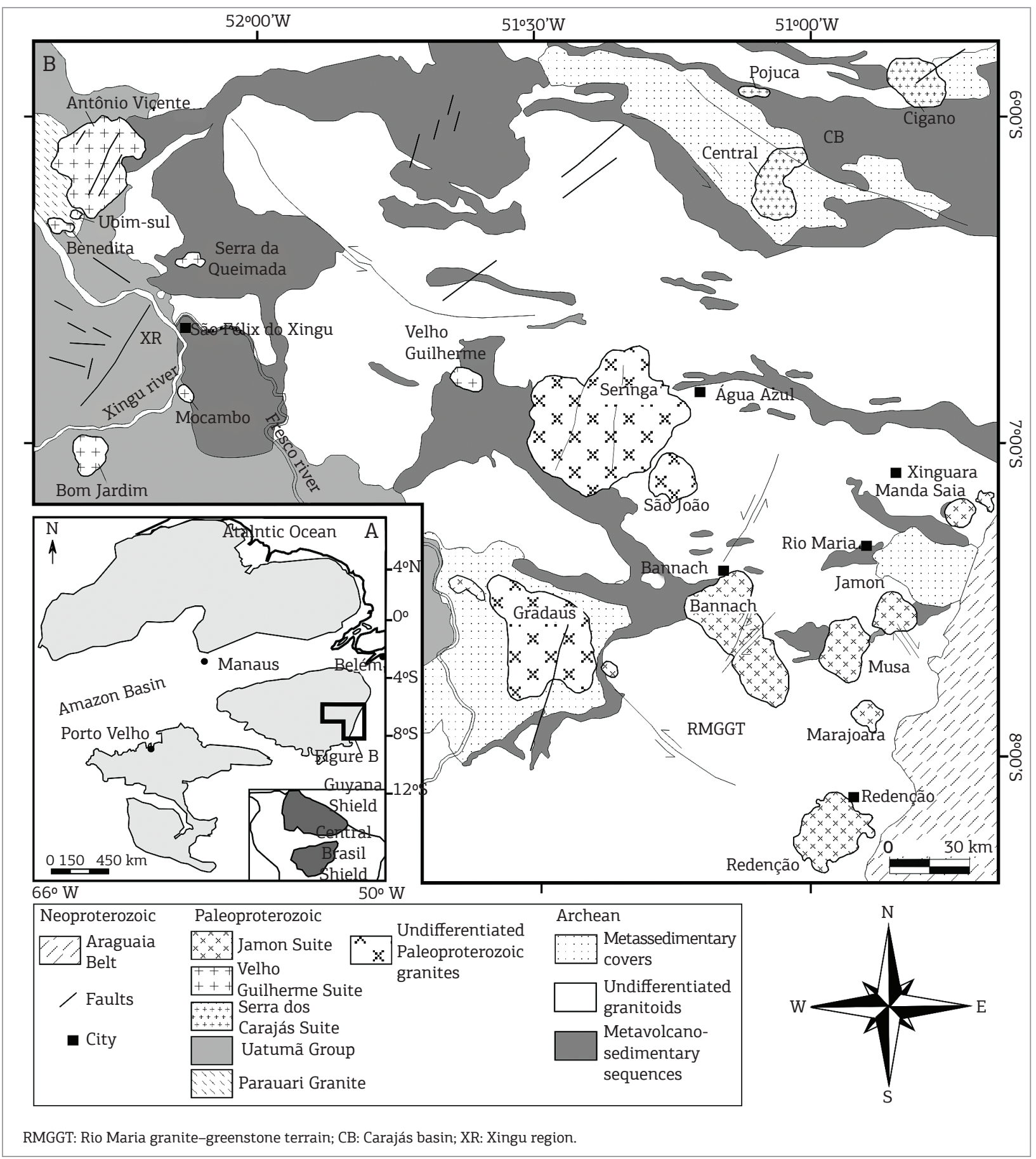

Figure 1. Simplified geological map of the Carajás Province showing the distribution of A-type granites that comprise the Paleoproterozoic granite suites. (modified from Dall'Agnol et al. 2005).

\section{VELHO GUILHERME SUITE}

Zircons of the VGS show subhedral shapes in the less evolved rocks, becoming dominantly anhedral and rounded in the most evolved and associated greisens (Figs. 4 and 5). In the latter, the zircons are strongly corroded, with dark $\mathrm{Ca}$-enriched patches and frequent inclusions of minerals of Th, $U$ and REE, indicating that the crystals were affected by hydrothermal processes responsible for formation of these rocks. In syenogranite rocks and greisens of the Bom Jardim granite, the zircons are associated with anhedral crystals of cassiterite and columbite (Fig. 4F), and show great morphological similarity with those of the evolved rocks and greisens of the SCS (Fig. 3). Compositionally, zircons of the VGS have Hf contents higher than 2.5 wt.\%, with the exception of zircons from the less evolved rocks (BASMG and BMG) of the Antônio Vicente granite (1.9 and 2.2 wt.\%, respectively) and zircons from the heterogranular syenogranite rocks of 
Table 2. The average chemical analysis (wt.\%) of investigated zircon grains performed by EDS

\begin{tabular}{|c|c|c|c|c|c|c|c|c|c|c|c|c|c|c|c|}
\hline $\begin{array}{l}\text { Suite/ } \\
\text { Granite }\end{array}$ & Facies & Sample & 0 & $\mathbf{S i}$ & $\mathrm{Ca}$ & $\mathbf{Y}$ & $\mathrm{Zr}$ & $\mathrm{Nb}$ & Hf & $\mathrm{Ta}$ & Th & $\mathrm{U}$ & $\begin{array}{l}\mathrm{Zr} / \\
\mathrm{Hf}\end{array}$ & $\mathrm{Zr} / \mathrm{Y}$ & $\boldsymbol{\Sigma}$ \\
\hline \multicolumn{16}{|l|}{ JAMON } \\
\hline \multirow{3}{*}{ Jamon (249) } & ABMG & $\begin{array}{c}\mathrm{AU}-390 \\
(74)\end{array}$ & 26.2 & 13.1 & 0.1 & 0.7 & 53.8 & 1.2 & 2.0 & 0.8 & 0.2 & 0.2 & 27.9 & 78.6 & 3.1 \\
\hline & BMGH & $\begin{array}{c}\text { AU-375 } \\
(126)\end{array}$ & 26.2 & 13.2 & 0.1 & 0.8 & 53.7 & 1.2 & 1.9 & 0.8 & 0.2 & 0.2 & 28.6 & 76.1 & 3.0 \\
\hline & BMG & $\begin{array}{c}\text { AU-382 } \\
(49)\end{array}$ & 27.3 & 13.1 & 0.5 & 0.8 & 51.7 & 1.2 & 2.3 & 0.8 & 0.2 & 0.2 & 23.6 & 81.2 & 3.6 \\
\hline \multirow{4}{*}{$\begin{array}{l}\text { Redenção } \\
(322)\end{array}$} & ABMG & $\begin{array}{c}\text { DCR-36B } \\
(124)\end{array}$ & 24.9 & 13.2 & 0.1 & 0.9 & 54.4 & 1.1 & 2.1 & 1.0 & 0.2 & 0.2 & 26.8 & 64.0 & 3.4 \\
\hline & BMG & $\begin{array}{c}\text { DCR-33B } \\
(98)\end{array}$ & 26.9 & 13.2 & 0.3 & 0.8 & 52.4 & 1.2 & 2.3 & 0.8 & 0.2 & 0.2 & 24.0 & 66.0 & 3.6 \\
\hline & Leucogr. & $\begin{array}{c}\text { DCR-83B } \\
(100)\end{array}$ & 26.4 & 13.1 & 0.5 & 1.5 & 51.8 & 1.1 & 2.2 & 1.0 & 0.2 & 0.3 & 24.7 & 56.5 & 4.2 \\
\hline & & Average & 26.3 & 13.1 & 0.3 & 0.9 & 53.0 & 1.2 & 2.1 & 0.9 & 0.2 & 0.2 & 25.9 & 70.4 & 3.5 \\
\hline \multicolumn{16}{|l|}{$\begin{array}{l}\text { SERRA DOS } \\
\text { CARAJÁS }\end{array}$} \\
\hline \multirow{4}{*}{$\begin{array}{l}\text { Central } \\
(462)\end{array}$} & ABMG & $\begin{array}{l}\text { GF1-26,7 } \\
(171)\end{array}$ & 28.1 & 13.0 & 0.6 & 0.8 & 51.3 & 1.1 & 2.2 & 0.8 & 0.2 & 0.3 & 24.5 & 67.5 & 3.5 \\
\hline & ABMG & $\begin{array}{l}\text { CRD-01 } \\
(123)\end{array}$ & 28.9 & 12.7 & 1.1 & 1.2 & 49.6 & 1.1 & 2.2 & 0.8 & 0.1 & 0.5 & 23.3 & 60.2 & 4.0 \\
\hline & ABSG & $\begin{array}{l}\text { CRD-04 } \\
(65)\end{array}$ & 30.0 & 12.7 & 1.3 & 1.0 & 47.7 & 1.0 & 2.7 & 0.9 & 0.2 & 0.5 & 19.0 & 60.0 & 4.4 \\
\hline & BSG & $\begin{array}{l}\text { MR-158 } \\
(103)\end{array}$ & 28.3 & 12.7 & 0.7 & 1.2 & 48.4 & 1.0 & 3.9 & 0.8 & 0.1 & 0.8 & 15.9 & 56.3 & 6.0 \\
\hline \multirow{4}{*}{ Cigano (550) } & ABMGP & 34-A (85) & 27.0 & 13.3 & 1.5 & 1.1 & 50.1 & 1.1 & 2.1 & 0.9 & 0.3 & 0.5 & 24.5 & 55.1 & 4.0 \\
\hline & BMG & $\begin{array}{c}\text { ECR-91B } \\
(131)\end{array}$ & 24.6 & 13.3 & 0.4 & 0.8 & 54.1 & 1.2 & 2.2 & 0.9 & 0.3 & 0.3 & 25.8 & 75.5 & 3.6 \\
\hline & BMSG & 96 (120) & 24.1 & 13.4 & 0.7 & 1.0 & 53.8 & 1.2 & 2.2 & 0.9 & 0.3 & 0.4 & 25.4 & 63.5 & 3.9 \\
\hline & Greisen & $\begin{array}{l}\text { CIG-5 } \\
(214)\end{array}$ & 23.6 & 12.8 & 0.4 & 0.9 & 55.6 & 1.8 & 2.6 & 0.8 & 0.2 & 0.3 & 22.8 & 62.3 & 4.0 \\
\hline \multirow{6}{*}{ Pojuca (553) } & ABMG & F-11 (117) & 26.9 & 13.0 & 0.9 & 0.8 & 51.9 & 1.2 & 2.6 & 0.8 & 0.2 & 0.4 & 21.7 & 76.2 & 4.0 \\
\hline & $\mathrm{BMG}$ & F-33 (131) & 26.7 & 11.8 & 1.5 & 0.9 & 43.7 & 0.9 & 3.7 & 0.6 & 0.3 & 0.6 & 12.1 & 59.3 & 5.5 \\
\hline & BMSG & F-6 (153) & 29.4 & 12.7 & 1.5 & 1.1 & 47.5 & 1.4 & 2.7 & 1.0 & 0.4 & 0.4 & 20.5 & 65.6 & 4.6 \\
\hline & Leucogr. & F-30 (72) & 30.2 & 12.9 & 1.5 & 1.6 & 43.6 & 0.9 & 5.5 & 0.6 & 0.7 & 0.8 & 8.1 & 50.3 & 8.6 \\
\hline & Hydr. L. & F-36 (80) & 28.6 & 12.6 & 1.0 & 1.6 & 44.7 & 1.0 & 5.8 & 0.6 & 0.4 & 0.6 & 7.6 & 66.4 & 8.4 \\
\hline & & Average & 27.4 & 12.8 & 1.0 & 1.1 & 49.4 & 1.2 & 3.1 & 0.8 & 0.3 & 0.5 & 19.3 & 62.9 & 5.0 \\
\hline
\end{tabular}


Table 2. Continuation

\begin{tabular}{|c|c|c|c|c|c|c|c|c|c|c|c|c|c|c|c|}
\hline $\begin{array}{l}\text { Suite/ } \\
\text { Granite }\end{array}$ & Facies & Sample & 0 & $\mathrm{Si}$ & $\mathrm{Ca}$ & $\mathbf{Y}$ & $\mathrm{Zr}$ & $\mathrm{Nb}$ & Hf & Ta & Th & $\mathbf{U}$ & $\begin{array}{l}\mathrm{Zr} / \\
\mathrm{Hf}\end{array}$ & $\mathrm{Zr} / \mathrm{Y}$ & $\boldsymbol{\Sigma}$ \\
\hline \multicolumn{16}{|c|}{ VELHO GUILHERME } \\
\hline \multirow{6}{*}{$\begin{array}{l}\text { Antonio } \\
\text { Vicente } \\
(450)\end{array}$} & BASMG & IE-02 (76) & 27.6 & 12.7 & 0.2 & 0.8 & 52.1 & 1.6 & 1.9 & 0.9 & 0.2 & 0.2 & 29.6 & 70.1 & 3.1 \\
\hline & BMG & $\begin{array}{c}\text { GAMCS54 } \\
(38)\end{array}$ & 28.9 & 12.3 & 0.6 & 1.2 & 49.9 & 1.0 & 2.2 & 1.0 & 0.3 & 0.4 & 23.1 & 55.7 & 4.1 \\
\hline & BSGA & $\begin{array}{l}\text { AVBA4 } \\
(96)\end{array}$ & 27.4 & 12.6 & 0.9 & 0.9 & 51.2 & 0.9 & 2.6 & 1.0 & 0.2 & 0.5 & 22.0 & 62.4 & 4.2 \\
\hline & BSGIA & $\begin{array}{l}\text { NEB75 } \\
(70)\end{array}$ & 29.8 & 12.3 & 0.9 & 1.4 & 47.8 & 0.9 & 2.9 & 0.9 & 0.2 & 0.8 & 18.1 & 58.5 & 5.3 \\
\hline & $\begin{array}{c}\text { Greisen } \\
1\end{array}$ & $\begin{array}{l}\text { AVIN10 } \\
(92)\end{array}$ & 27.9 & 11.5 & 0.5 & 2.5 & 48.5 & 1.1 & 3.2 & 0.9 & 0.9 & 0.5 & 17.2 & 59.5 & 7.1 \\
\hline & $\begin{array}{c}\text { Greisen } \\
2\end{array}$ & $\begin{array}{l}\text { NRAV26B } \\
(78)\end{array}$ & 28.5 & 12.6 & 0.4 & 1.1 & 50.4 & 1.2 & 2.5 & 0.8 & 0.1 & 0.4 & 21.9 & 56.4 & 4.1 \\
\hline \multirow{5}{*}{$\begin{array}{l}\text { Bom Jardim } \\
\text { (439) }\end{array}$} & BMG & $\begin{array}{l}\text { SAL72 } \\
(123)\end{array}$ & 33.3 & 11.5 & 0.6 & 6.4 & 38.5 & 0.8 & 3.7 & 0.7 & 0.5 & 1.1 & 11.7 & 17.4 & 11.7 \\
\hline & BMG & $\begin{array}{c}\text { SAL29 } \\
(114)\end{array}$ & 31.7 & 11.7 & 0.3 & 1.2 & 45.2 & 0.9 & 3.9 & 0.7 & 1.5 & 0.8 & 13.1 & 55.9 & 7.4 \\
\hline & BSG & $\begin{array}{c}\text { SAL-49 } \\
(81)\end{array}$ & 30.2 & 11.8 & 1.3 & 1.7 & 44.0 & 1.3 & 5.4 & 0.7 & 0.4 & 1.0 & 8.5 & 51.6 & 8.5 \\
\hline & $\begin{array}{c}\text { Greisen } \\
1\end{array}$ & $\begin{array}{l}\text { SAL-100 } \\
(79)\end{array}$ & 31.4 & 11.3 & 0.5 & 1.5 & 45.8 & 0.7 & 3.4 & 0.9 & 0.7 & 1.6 & 14.2 & 52.9 & 7.2 \\
\hline & $\begin{array}{c}\text { Greisen } \\
2\end{array}$ & $\begin{array}{c}\text { SAL-66b } \\
(42)\end{array}$ & 30.6 & 9.9 & 0.8 & 3.5 & 39.3 & 0.8 & 5.8 & 0.8 & 3.3 & 2.5 & 7.0 & 20.6 & 15.1 \\
\hline \multirow{3}{*}{$\begin{array}{l}\text { Mocambo } \\
\text { (200) }\end{array}$} & PSMG & $\begin{array}{c}\text { GM-56A } \\
\text { (55) }\end{array}$ & 23.3 & 11.7 & 0.5 & 1.5 & 53.1 & 0.6 & 3.7 & 2.4 & 0.4 & 1.2 & 15.2 & 61.4 & 6.8 \\
\hline & PSMG & $\begin{array}{c}\text { GM-17B } \\
(68)\end{array}$ & 24.8 & 11.7 & 0.7 & 2.1 & 50.7 & 0.6 & 4.0 & 2.1 & 0.6 & 0.9 & 14.5 & 53.3 & 7.6 \\
\hline & Greisen & $\begin{array}{c}\text { GM-23A } \\
(77)\end{array}$ & 24.6 & 12.4 & 0.6 & 1.3 & 52.8 & 0.7 & 3.1 & 1.9 & 0.2 & 0.6 & 17.5 & 52.0 & 5.2 \\
\hline \multirow{2}{*}{$\begin{array}{l}\text { Serra da } \\
\text { Queimada } \\
(161)\end{array}$} & BMG & SQ22 (71) & 26.1 & 11.7 & 1.1 & 3.1 & 48.7 & 1.7 & 3.0 & 0.9 & 0.9 & 1.1 & 17.0 & 34.4 & 8.1 \\
\hline & BSG & SQ11 (90) & 27.4 & 12.1 & 1.0 & 2.2 & 48.3 & 1.5 & 3.5 & 0.8 & 0.4 & 1.0 & 15.0 & 35.6 & 7.1 \\
\hline \multirow{2}{*}{$\begin{array}{l}\text { Velho } \\
\text { Guilherme } \\
(104)\end{array}$} & HSG & $\begin{array}{c}\text { NNVG-38 } \\
(58)\end{array}$ & 25.6 & 12.9 & 0.2 & 0.9 & 53.9 & 1.0 & 2.1 & 1.1 & 0.2 & 0.2 & 26.9 & 64.7 & 3.4 \\
\hline & ESG & $\begin{array}{c}\text { NNVG-31 } \\
(46)\end{array}$ & 31.4 & 12.1 & 1.0 & 5.4 & 41.7 & 0.8 & 2.8 & 1.3 & 0.7 & 0.5 & 16.3 & 26.6 & 9.4 \\
\hline $\begin{array}{l}\text { Total of } \\
\text { analysis }= \\
3,490\end{array}$ & & Average & 28.4 & 11.9 & 0.7 & 2.2 & 47.9 & 1.0 & 3.3 & 1.1 & 0.6 & 0.8 & 17.2 & 49.4 & 7.0 \\
\hline
\end{tabular}

ABMG: amphibole-biotite monzogranite; HBMG: heterogranular biotite monzogranite; BMG: biotite monzogranite; PABMG: porphyritic amphibole-biotite monzogranite; BMSG: biotite monzogranito to syenogranite; BASMG: biotite-amphibole syenogranite to monzogranite; PSMG: porphyritic syenogranite to monzogranite; HSG: heterogranular syenogranite; ESG: equigranular syenogranite; Leucogr.: leucogranite; Hydr. L.: hydrothermalized leucogranite; A: altered; I: intensely. $\Sigma$ : sum $\mathrm{Hf}+\mathrm{Y}+\mathrm{Th}+\mathrm{U}(\mathrm{ppm})$. Number of analyses in parentheses. 
the Velho Guilherme pluton (2.1 wt.\%). Zircon crystals of the monzogranites rocks of the Mocambo and Bom Jardim granites and greisens associated with the Antônio Vicente granite have clearer and intensely corroded rims surrounding more preserved and, it seems, older cores (Figs. 4D and 4E and 5A). In the zircons of the Bom Jardim granite, such rims include contents of up to 3.9 wt.\% Hf, 5.1 wt.\% Th and 1.8 wt.\% U, whereas the cores showed concentrations of $2.9 \mathrm{wt} . \% \mathrm{Hf}$ and $0.5 \mathrm{wt} . \%$ for both Th and U. In the Mocambo granite, the Hf contents in the edges of some crystals reached 5.0 wt.\% (Fig. 5A). In the greisens of the Antônio Vicente granite, the Hf contents in the rim zone of the zircons reached $5.9 \mathrm{wt} . \%$; however, the contents of Th and U did not exceed 1.0 wt.\% (Fig. 4D).

Zircons of the VGS showed a mean Hf content of $3.3 \mathrm{wt} . \%$ and the lowest $\mathrm{Zr} / \mathrm{Hf}$ mean ratio (17.2) among the three suites. $\mathrm{Y}$, Th and $\mathrm{U}$ show average grades (2.2, 0.6 and $0.8 \mathrm{wt} . \%$, respectively), slightly higher than those of the zircons from the other two suites and yielding average $\mathrm{Zr} / \mathrm{Y}$ ratios comparatively lower (49.4, Tab. 2) than the other two suites. Hf $+\mathrm{Y}+$ $\mathrm{U}+$ Th of the VGS zircons vary from $3.1 \mathrm{wt} . \%$ in amphibole monzogranites of the Antônio Vicente granite to 15.1 wt.\% in greisens of the Bom Jardim pluton, with an average value of $7.0 \mathrm{wt} . \%$. The average content of $\mathrm{Nb}$ and $\mathrm{Ta}$ is 1.0 and 1.1 wt. $\%$, slightly lower and higher, respectively, compared with the contents in zircons of the other two granitic suites.

\section{DISCUSSION}

\section{Zircon as an indicator \\ of specialized granites}

Systematic studies on the geochemical signature of zircon, reflected in the abundance of certain trace elements, especially Hf, indicate that zircon can be used as a geochemical tracer. Such data may be useful in identifying the nature of their source rocks and crystallization environment, in the characterization of magmatic fractionation processes and in provenance studies of detrital zircons (Heaman et al. 1990; Uher et al. 1998; Hoskin \& Ireland 2000; Pupin 2000; Wang et al. 2000; Belousova \& Grifffin 2002). This is because $\mathrm{Zr}$ and $\mathrm{Hf}$ have similar ionic radii and electrical charges. Because most of the $\mathrm{Zr}$ and $\mathrm{Hf}$ contents in granitic rocks are incorporated into zircon crystals, the $\mathrm{Zr} / \mathrm{Hf}$ ratio of this mineral can be considered to approximate the $\mathrm{Zr} / \mathrm{Hf}$ ratio of the source magma (Owen 1987). Wang et al. (1996) concluded that Hf-rich zircons from S-type granites of Suzhou (China) have formed as a result of fractional crystallization processes, which would indicate the tendency of enrichment in that element during magmatic differentiation. Zircons of peralkaline granites of Laoshan complex, China, also have Hf-enriched edges, but the same rocks were interpreted by Wang et al. (1996) as resulting from hydrothermal activities. Wang et al. (2000) assumed that zircons from granitic rocks with high levels of $\mathrm{Hf}$ are typical of evolved granites also enriched in rare metals ( $\mathrm{Sn}, \mathrm{Mo}, \mathrm{Ta}, \mathrm{W}, \mathrm{Li}$ ), and high-Hf zircon occurrence would mark the passage from granite to pegmatites with rare metals. Kempe et al. (2004) demonstrated that granites with topaz and rare metals have extremely low $\mathrm{Zr} / \mathrm{Hf}$ ratios, interpreted as a primary signature of evolved granitic liquids or, alternatively, as a signature produced during processes of albitization of the host rocks by F-enriched fluids. Lamarão et al. (2007, 2010, 2012) performed compositional and textural studies of zircons by SEM-EDS from granites and associated greisens from tin provinces of southern Pará, Pitinga and Rondônia, and compared the data with those provided by zircons from granites without tin in the south-eastern Amazon Craton. The zircons from tin granites showed Hf enrichment and lower $\mathrm{Zr} / \mathrm{Hf}$ ratios than those of granites without tin, indicating that a geochemical signature of zircon can be used, even through semi-quantitative EDS analysis, as a preliminary indicator of specialized granites.

\section{Composition of zircons and the metallogenic potential of the studied granitic suites}

Zircons from tin granites of the VGS are predominantly anhedral, altered and corroded, especially in the more evolved rocks and associated greisens (Figs. 4 and 5). Compositionally, they are more enriched in Hf, Y, Th and $\mathrm{U}$, have lower $\mathrm{Zr}$ / $\mathrm{Hf}$ and $\mathrm{Zr} / \mathrm{Y}$ ratios and the highest values of $\mathrm{Hf}+\mathrm{Y}+\mathrm{U}+\mathrm{Th}$ compared with zircons of the other two suites (Tab. 1). In general, these elements tend to increase in the more evolved rocks (e.g., in the Antônio Vicente and Bom Jardim granites), suggesting that magmatic differentiation plays an important role in this enrichment (Wang et al. 1996, 2000). In some cases, zircons of greisens associated with these granites have concentrations of these elements that are similar or higher than those of zircons from magmatic facies formed during the magmatic stage (e.g., greisens of the Antônio Vicente and Bom Jardim granites). Furthermore, some zircons have overgrowth edges that are heavily corroded and enriched in Hf, Y, Th and U relative to their cores (Figs. $4 \mathrm{E}$ and $5 \mathrm{~A}$ ), suggesting that tardi-magmatic fluids may have caused textural changes as well as enrichment in these trace elements in the early zircons (Wang et al. 1996). Textural features resulting from overgrowth may also have developed in sub-solidus conditions during the stage of greisenization, as found in zircons from greisens associated with the Antônio Vicente pluton (Fig. 4D).

In the SCS, the Pojuca granite (Horbe 1998) has zircons with morphological and compositional characteristics closer to those of zircons from tin granites of the VGS (Fig. 3, Tab. 2). The high content of Hf and the low $\mathrm{Zr} / \mathrm{Hf}$ ratios present, especially in zircons from leucogranites, 

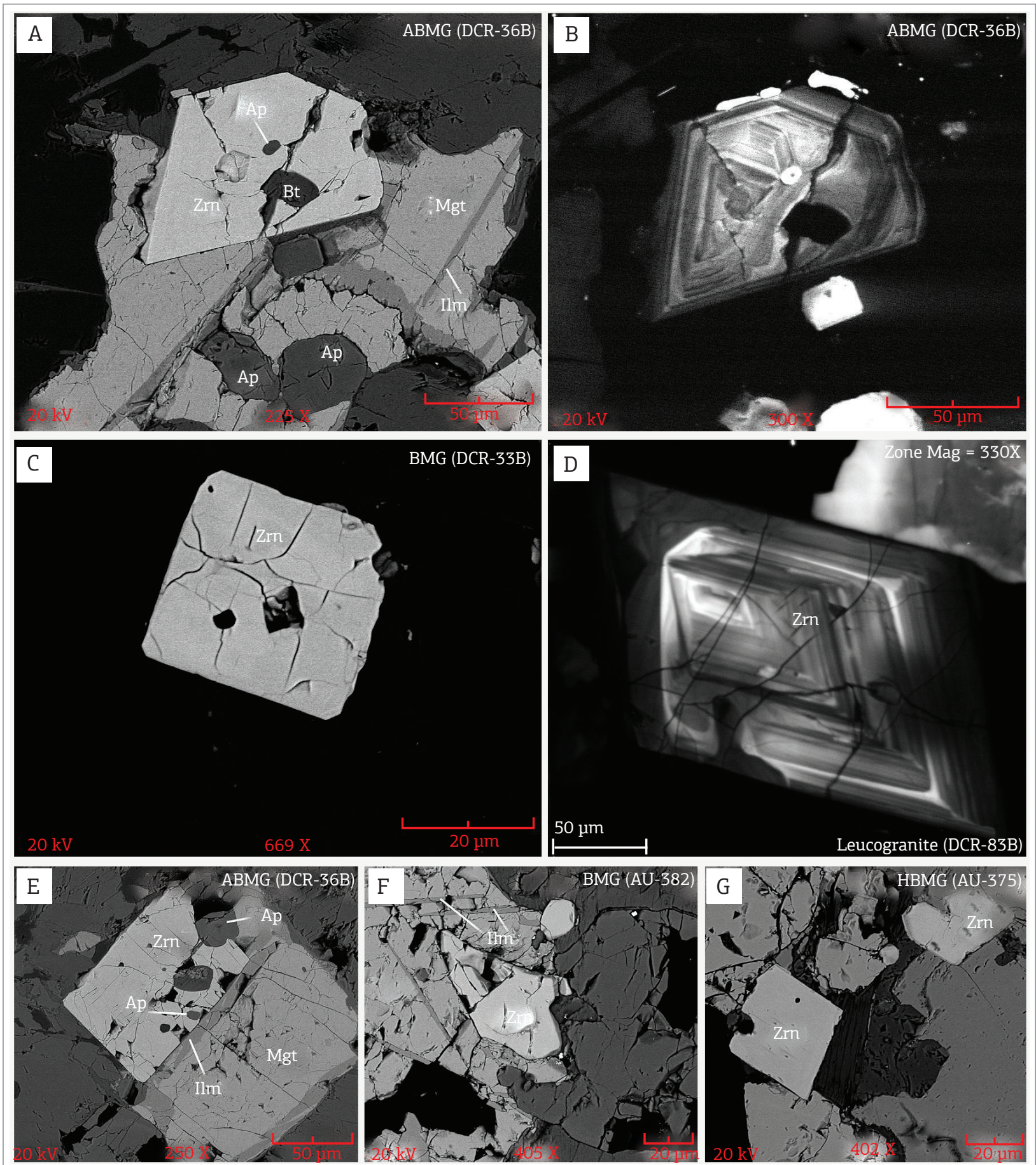

Zrn: zircon; Ap: apatite; Mgt: magnetite; Ilm: ilmenite; Bt: biotite; BMG: biotite monzogranite; A: amphibole; H: heterogranular.

Figure 2. Images of backscattered electron (A, C, E, F and G) and cathodoluminescence (B and D) of zircons from the Redenção (A-D) and Jamon (E-G) granites.

suggest that the more evolved varieties of the Pojuca pluton have the potential to generate tin mineralization. However, even in these more evolved rocks, the SEM analyses found no presence of cassiterite, suggesting that factors other than composition can lead to the development of tin mineralization. In Central granites, despite the intense alteration and corrosion present in zircons (Figs. 3A to 3C), the levels of
$\mathrm{Hf}$ and $\mathrm{Y}$ are, except in the syenogranites, lower and have $\mathrm{Zr} / \mathrm{Hf}$ and $\mathrm{Zr} / \mathrm{Y}$ ratios higher than those of the typical tin granites of the VGS (Tab. 2). Rios et al. (1995) and Barros et al. (1995) performed petrographic and metallogenic evaluation of the potential in the northern and western portions, respectively, of the Central granite and did not identify any evidence of magmatic or hydrothermal tin mineralization, 


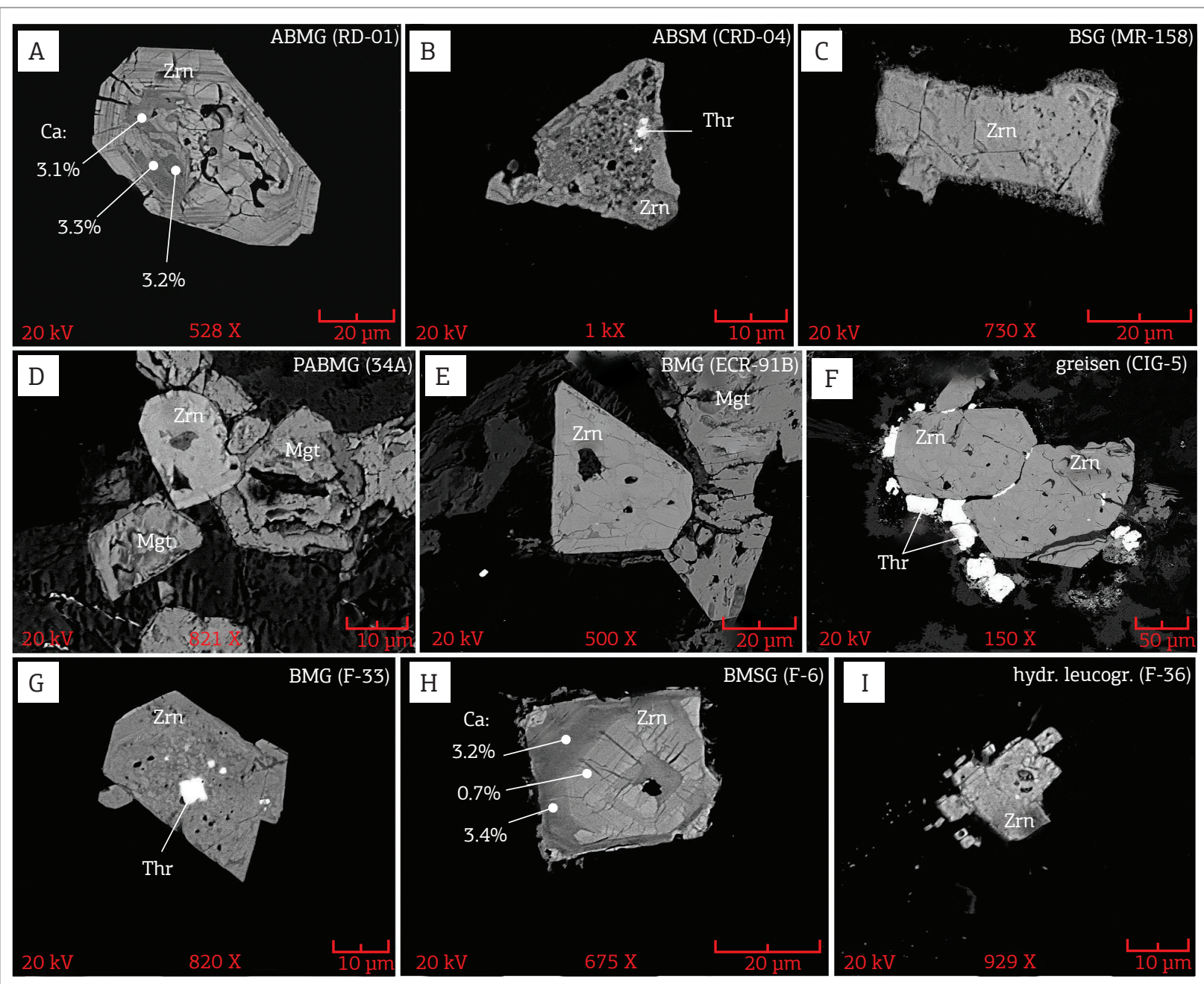

Zrn: zircon; Thr: thorite; Mgt: magnetite; BMG: biotite monzogranite; A: amphibole; P: porphyritic; S: syenogranite; hydr. leucogr.: hydrothermal leucogranite.

Figure 3. Backscattered electron images of zircons from the Central (A - C), Cigano (D - F) and Pojuca (G - I) granites of the Serra dos Carajás suite. (A) Altered, fractured and corroded euhedral crystal; dark patches with high contents of $\mathrm{Ca}$; (B) Anhedral crystal intensely corroded showing sieve texture and fine thorite inclusions; (C) Fractured and corroded anhedral crystal; (D - F) Altered and fractured subhedral crystals associated with magnetite and thorite crystals; (G) Subhedral and corroded crystal, displaying sieve aspect on the central portion and fine thorite inclusions; $(\mathrm{H})$ Compositionally zoned and fractured crystal, showing Ca-enriched dark zones in relation to light zone; (I) Thin zircon crystal intensely altered.

such as albite granites, greisens or rocks containing siderophyllite and/or topaz. The petrographic and geochemical characteristics observed contrast with the granites specialized in Sn. Greisens associated with Cigano granite have zircons with the $\mathrm{Zr} / \mathrm{Hf}$ ratios very similar $(\sim 23)$ to those found in zircons from monzogranite and syenogranite rocks $(24-26)$ and were also not identified as having Sn mineralization in this body, indicating that the geochemical signature of magmatic zircons was most likely preserved during the stage of greisenization of the pluton.

In turn, Redenção and Jamon granites have well-developed zircons that are predominantly euhedral to subhedral, contain frequent inclusions of apatite (Fig. 2), are depleted in $\mathrm{Hf}$ and have $\mathrm{Zr} / \mathrm{Hf}$ ratios much higher than those of zircons from the other two suites (Tab. 2), which are all geochemical characteristics in agreement with their low potential for generating tin deposits. However, there are occurrences of wolframite in the Pedra Preta deposit at western edge of Musa granite (not investigated here). W can be associated with different types of granites and has little dependence on the oxidation state of the magma (Blevin \& Chappell 1992, 1995; Blevin et al. 1996). In the Pedra Preta deposit, the data suggest a metamorphic origin for the mineralizing solutions, although the Musa granite is an alternative for the origin of W (Rios et al. 2003). Figure 6 shows the variation of the $\mathrm{Zr} / \mathrm{Hf}$ ratios in zircons of the studied granites and indicates the associated mineralization with the same, whereas Fig. 7 compares these ratios to the contents of $\mathrm{Hf}+\mathrm{Y}+\mathrm{U}+\mathrm{Th}$ obtained by SEM-EDS. 

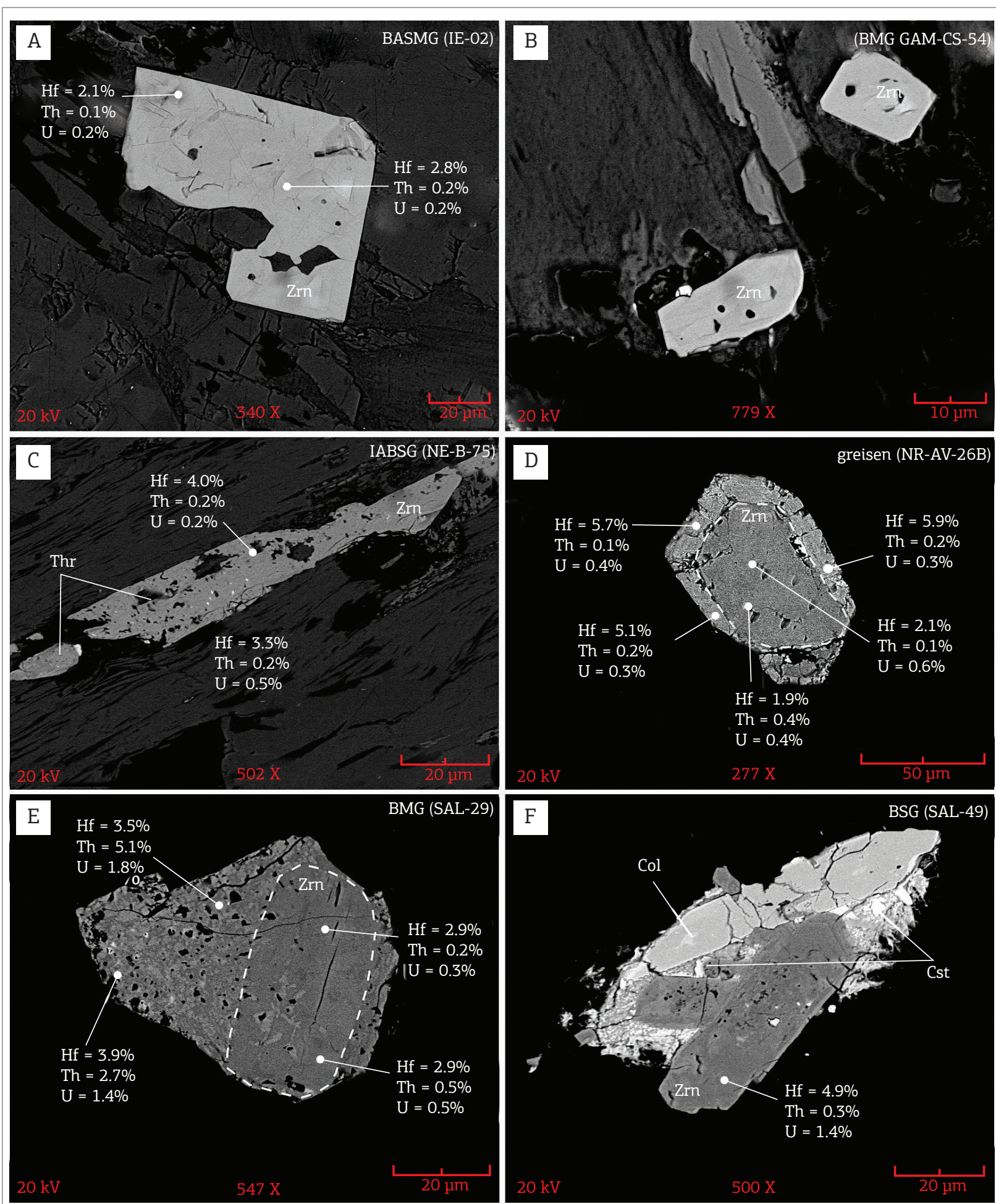

BASMG: biotite-amphibole syenogranite to monzogranite; BMG: biotite monzogranite; BSG: biotite syenogranite; IA: intensely altered; Zrn: zircon; Thr: thorite; Cst: cassiterite; Col: columbite.

Figure 4. Backscattered electron images with EDS analyses of zircons from Antonio Vicente (A - D) and Bom Jardim (E and F) granites, Velho Guilherme suite. (A and B) Subhedral and slightly altered crystals of less evolved facies (BASMG and BMG), with comparatively lower contents of Hf, Th and U; (C) Subhedral and corroded crystals containing inclusions of thorite and higher contents of Hf, Th and U; (D) Subhedral crystal slightly altered showing Hf-enriched overgrowth mantle in relation to its core; (E) Crystal with more homogeneous subhedral core and mantle heavily corroded. Note higher contents of Hf, Th and U in the latter. Subhedral zircon crystals with high contents of $\mathrm{Hf}$ and $\mathrm{U}$, associated with crystals of tin and columbite. 


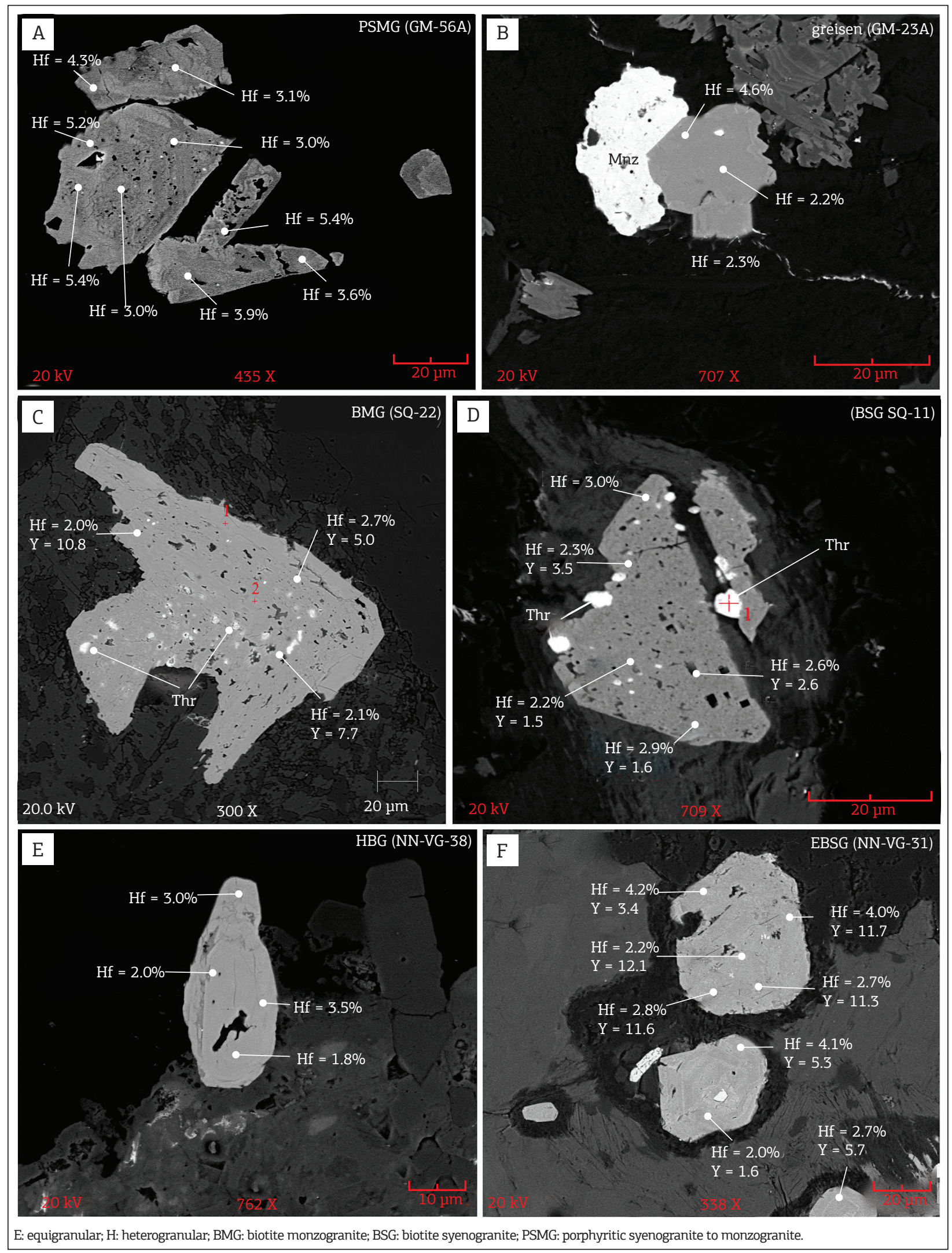

Figure 5. Backscattered electron images with EDS analyses of zircons from Mocambo (A and B), Serra da Queimada (C and D) and Velho Guilherme (E and F) granites, Velho Guilherme suite. (A) Altered and corroded crystals with Hf-enriched edges; (B) Anhedral crystals with higher Hf content at the edges associated to monazite crystals; (C and D) Anhedral and heavily corroded crystals, resembling to sieve with fine inclusions of thorite (Thr) and high concentrations of Y; (E and F) Subhedral to anhedral altered and corroded crystals showing variable concentrations of $\mathrm{Hf}$ and $\mathrm{Y}$. 
A frequency histogram with the $\mathrm{Zr} / \mathrm{Hf}$ ratios of the studied zircons (Fig. 8) shows that the zircons from granites of the VGS have the $\mathrm{Zr} / \mathrm{Hf}$ ratios comparatively lower than those of the JS, with a mode of 15 for the VGS and 25 for the JS. The zircons from plutons belonging to the SCS have $\mathrm{Zr} / \mathrm{Hf}$ ratios that span the range of values found in zircons of the VGS and JS, but the mode found for the ratios of zircons from the SCS was 22. The zircons from evolved rocks of the Pojuca and Central granites are responsible for the lower values of this ratio. The VGS samples mineralized in cassiterite, wolframite and columbite have zircon crystals with the $\mathrm{Zr} / \mathrm{Hf}$ ratios between 5 and 22 (Figs. 6 to 8).

\section{Composition of Zircons and Magmatic Series}

MS, mineral chemistry and experimental studies (Dall'Agnol et al. 1999b, 2005; Dall'Agnol \& Oliveira 2007; Oliveira et al. 2009b) demonstrate that the granites of the JS formed under predominantly oxidizing conditions (coincident or slightly higher than the buffer nickel/nickel oxide (NNO), whereas the dominant syenogranites of the VGS (Teixeira et al. 2002) evolved under reducing conditions (lower than the
fayalite-magnetite-quartz-FMQ - buffer), fitting, respectively, in magnetite and ilmenite series of Ishihara (1981). In the SCS, the dominant $\mathrm{Fe}$-Ti oxide mineral is magnetite, suggesting that these rocks were formed under oxidizing conditions. However, there is an apparent contradiction because the $\mathrm{Fe} /(\mathrm{Fe}+\mathrm{Mg})$ ratios obtained in whole rock, amphibole and biotite are very high and compatible with those of reduced granites (Dall'Agnol et al. 2005; Dall'Agnol \& Oliveira 2007). For this reason, the authors conclude that the granites of the SCS formed in moderately reduced conditions, situated above the FMQ buffer, to justify the presence of magnetite, but near the buffer to explain the high $\mathrm{Fe} /(\mathrm{Fe}+\mathrm{Mg})$ ratios. Sn mineralization is commonly associated with reduced granites of ilmenite series (Ishihara 1980). These may be accompanied by W and Ta mineralization, but there are also W-mineralized granites formed under oxidizing conditions (Blevin \& Chappell 1992, 1995; Blevin et al. 1996). This would explain the occurrence of this type of mineralization associated with bodies of the JS.

In this context, the zircon compositional data obtained in this study corroborate the characterization of the metallogenetic potential of the three suites from Carajás Province, as demonstrated by the occurrence of hydrothermal mineralization of

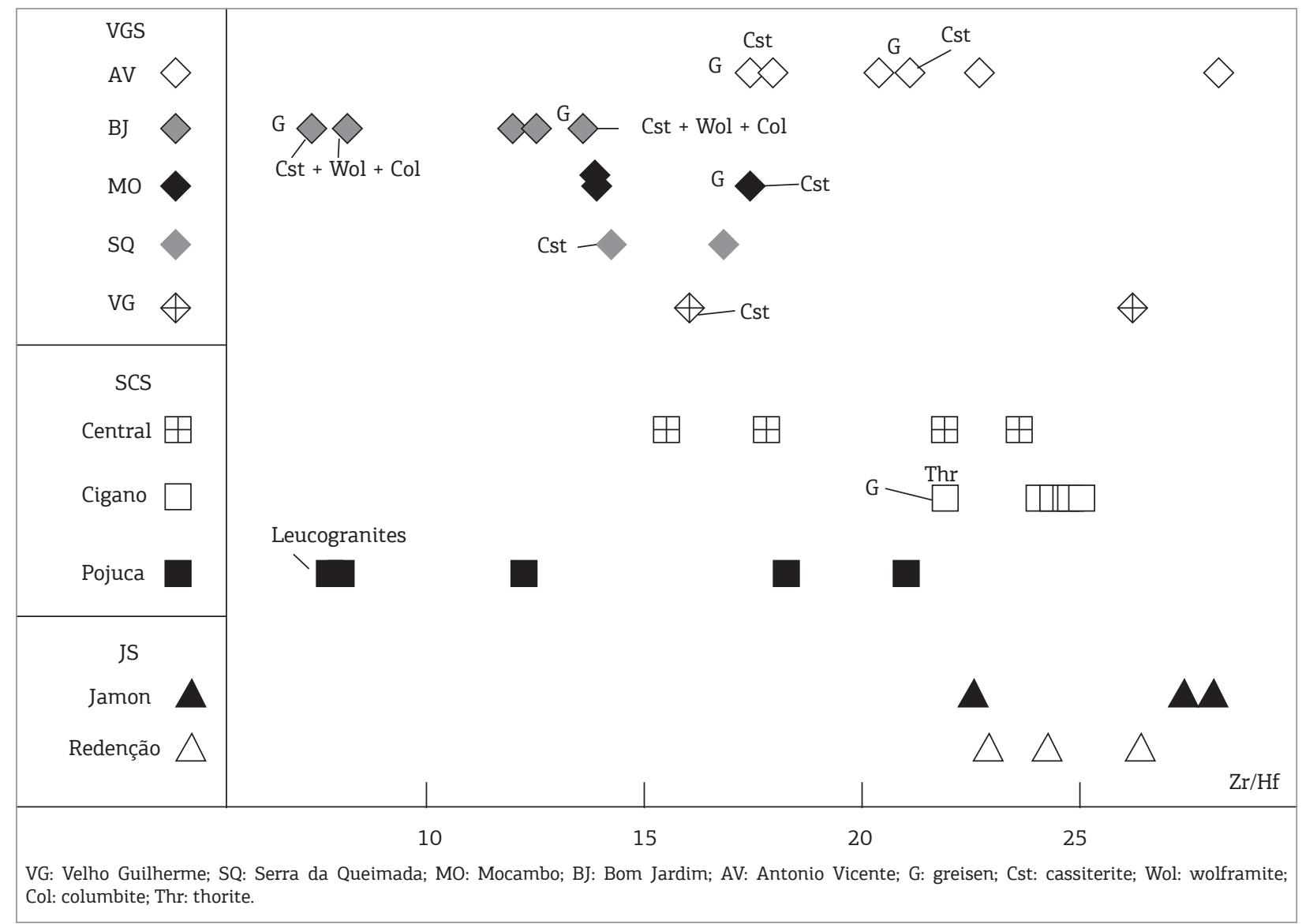

Figure 6. Distribution of $\mathrm{Zr} / \mathrm{Hf}$ means ratios of zircons from magmatic and hydrothermal facies associated with each of the plutons of the studied suites: Jamon suite (JS), Serra dos Carajás suite (SCS) and Velho Guilherme suite (VGS). 
Sn associated with reduced rocks of the VGS, and its absence in granites of the oxidized JS. The SCS is located in intermediate conditions in relation to the other two suites in terms of oxygen fugacity (Dall'Agnol et al. 2005; Dall'Agnol \& Oliveira 2007) and shows morphological and compositional variations of zircons similar to the tin granites of the VGS. Although no Sn mineralization associated with this suite has been identified, occurrences of anomalies of tin were detected at the north-west edge of the Central granite (Barros et al. 1995). This indicates that although this suite is not the most favorable for tin mineralization, its characteristics are not entirely incompatible with those of specialized granites. Therefore, tin mineralization could occur associated with their more evolved facies, but would likely be of small volume and less expressive than the mineralization associated with the VGS.

\section{CONCLUSIONS}

Zircons of the three granitic suites show remarkable compositional and morphological differences. In the JS, they form euhedral to subhedral well-developed crystals, without evident alteration and corrosion. In terms of composition, they have low contents of $\mathrm{Hf}, \mathrm{Y}$, Th and $\mathrm{U}$; their higher $\mathrm{Zr} / \mathrm{Hf}$ ratios, even in its most evolved rocks (leucogranites of the Redenção granite), indicate a very low potential for the generation of Sn deposits compared to zircons from the granites of the other two studied suites. Zircons from tin granites of the VGS are subhedral in the less evolved rocks (BASMG) to dominantly anhedral, altered and strongly corroded, Hf enriched and have $\mathrm{Zr} / \mathrm{Hf}$ ratios that

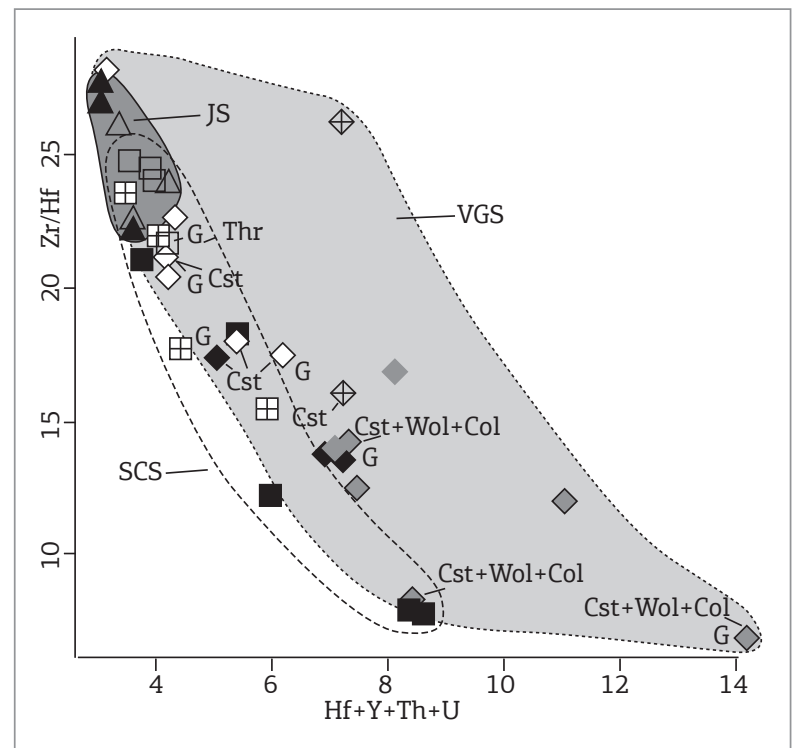

Figure 7. Zr/Hf versus $\mathrm{Hf}+\mathrm{Y}+\mathrm{U}+\mathrm{Th}$ diagram (wt.\%) of zircons from granites of the Jamon suite (JS), Serra dos Carajás suite (SCS) and Velho Guilherme suite (VGS). Symbols and abbreviations as in Fig. 6. decrease towards the more evolved rocks and associated greisens. The greisens mineralized in Sn, W and Ta of this suite contain zircons with the $\mathrm{Zr} / \mathrm{Hf}$ ratios between 5 and 22 , indicating that zircons from reduced granites with the $\mathrm{Zr} / \mathrm{Hf}$ ratios of this order may be used in preliminary prospective studies of specialized granite bodies. Zircons from the SCS showed medium contents of $\mathrm{Hf}+\mathrm{Y}+\mathrm{Th}+\mathrm{U}$ and $\mathrm{Zr} / \mathrm{Hf}$ ratios intermediate between those found in the zircons of the JS and VGS (Tab. 2). However, in the frequency histogram constructed from the total number of analyses performed in this study, the $\mathrm{Zr} / \mathrm{Hf}$ ratios of zircons from the SCS encompass the range of values yielded by the zircons of the JS and VGS. Although zircons of the Pojuca granite are morphologically and geochemically similar to those of the VGS, there were no observed occurrences of tin mineralization in its rocks. The occurrence of tin anomalies in stream sediments near the north-western edge of the Central granite of the SCS (Barros et al. 1995) indicates that the more evolved varieties of this suite can generate such mineralization. This can be explained by the moderately reducing character of its magma, which, though less favorable than in the case of the granites of the VGS, is not incompatible with generating the tin mineralization associated with their more evolved facies.

Greisens associated with Cigano granite do not have tin mineralization. The zircons found in these greisens have an average $\mathrm{Zr} / \mathrm{Hf}$ ratio that is similar to that of the host granite. Similar to observations in the Pitinga Province, the processes of greisenization apparently preserved the geochemical signature of the magmatic zircons. Zircon crystals found in greisens are generally remnants of the host granite.

This study showed the importance of the morphological features and geochemical signature of zircons, reflected mainly in their $\mathrm{Hf}$ contents and $\mathrm{Zr} / \mathrm{Hf}$ ratios, on

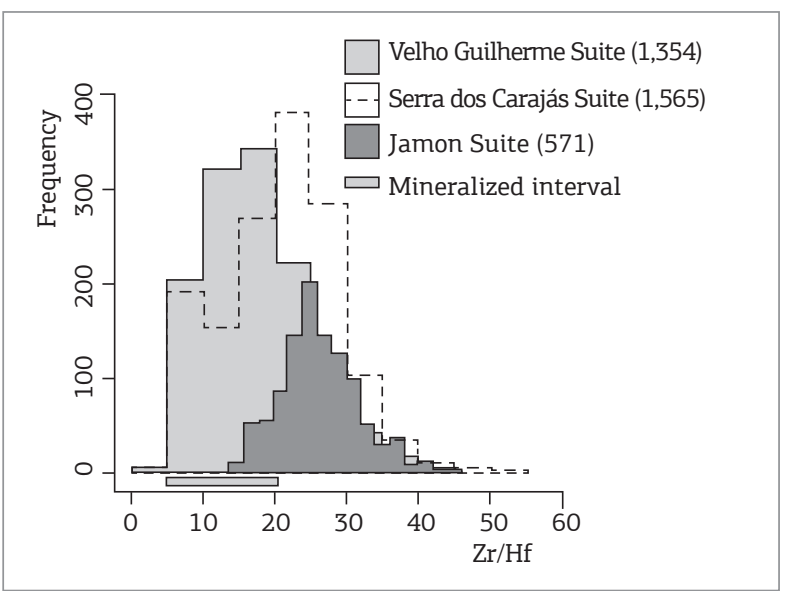

Figure 8. Frequency histogram showing $\mathrm{Zr} / \mathrm{Hf}$ ratios of zircons from granites of the Jamon, Serra dos Carajás and Velho Guilherme suites. Number of EDS analyses in parentheses. 
the identification of specialized tin granites. The chemical differences presented by the zircons of the three studied granitic suites corroborate the petrological, geochemical, and MS characteristics, allowing their individualization. Analysis of zircon by SEM-EDS can therefore be used in the preliminary evaluation of the granite metallogenetic potential for $\mathrm{Sn}$ mineralization and likely other metals.

\section{ACKNOWLEDGMENTS}

Geosciences Institute of UFPA and colleagues of the Group of Research on Granite Petrology of the UFPA. This paper is a contribution to the Amazonian Institute of Geosciences GEOCIAM, Program (INCT - CNPq/MCT/FAPESPA Proc. 573733/2008-2).

\section{REFERENCES}

Almeida J.A.C., Dall'Agnol R., Oliveira M.A., Macambira M.J.B., Pimentel M.M., Rämö O.T., Guimarães F.V., Leite A.A.S. 2011. Zircon geochronology and geochemistry of the TTG suites of the Rio Maria Granite-Greenstone terrain: Implications for the growth of the Archean crust of the Carajás Province, Brazil. Precambrian Research, 187:201-221.

Almeida J.A.C., Oliveira M.A., Dall'Agnol R., Althoff F.., Borges R.M.K. 2008. Relatório de mapeamento geológico na escala 1:100.000 da Folha Marajoara (SB-22-Z-C-V). Programa Geobrasil, CPRM - Serviço Geológico do Brasil, 147 p.

Barbosa A.A., Lafon J.M., Neves A.P., Vale A.G. 1995. Geocronologia Rb-Sr e $\mathrm{Pb}-\mathrm{Pb}$ do Granito Redenção, SE do Pará: Implicações para a evolução do magmatismo proterozóico da região de Redenção. Boletim do Museu Paraense Emílio Goeldi, Série Ciências da Terra, 7:147-164.

Barros C.E.M, Dall'Agnol R., Vieira E.A.P., Magalhães M.S. 1995. Granito Central da Serra dos Carajás: avaliação do potencial metalogenético para estanho com base em estudos da borda oeste do corpo. Boletim do Museu Paraense Emílio Goeldi, Série Ciências da Terra, 7:93-123.

Belousova E.A. \& Griffin W.L. 2002. Igneous zircon: Trace element composition as an indicator of source rock type. Contribution to Mineralogy and Petrology, 143:602-622.

Blevin P.L. \& Chappell B.W. 1992. The role of magma sources, oxidation states and fractionation in determining the granite metallogeny of eastern Australia. Transactions of the Royal Society of Edinburgh: Earth Sciences, 83:305-316.

Blevin P.L. \& Chappell B.W. 1995. Chemistry, origin and evolution of mineralized granites in the Lachlan Fold Belt, Australia: The metallogeny of I- and S-type granites. Economic Geology, 90:1604-1619.

Blevin P.L., Chappell B.W., Allen C.M. 1996. Intrusive metallogenic provinces in eastern Australia based on granite source and composition. Transactions of the Royal Society of Edinburgh: Earth Sciences, 87:281-290.

Dall'Agnol R., Rämö O.T., Magalhães M.S., Macambira M.J.B. 1999a. Petrology of the anorogenic, oxidized Jamon and Musa granites, Amazonian Craton: Implications for the genesis of Proterozoic A-type granites. Lithos, 46:431-462.

Dall'Agnol R., Scaillet B., Pichavant, M. 1999b. An experimental study of a lower Proterozoic A-type granite from the eastern Amazonian Craton, Brazil. Journal of Petrology, 40:1673-1698.

Dall'Agnol R., Teixeira N.P., Rämo O.T., Moura C.A.V., Macambira M.J.B., Oliveira D.C. 2005. Petrogenesis of the Paleoproterozoic rapakivi A-type granites of the Archean Carajás metallogenic province, Brazil. Lithos, 80:101-129.

Dall'Agnol R., Oliveira M.A., Almeida J.A.C., Althoff F.J., Leite A.A.S., Oliveira D.C., Barros C.E.M. 2006. Archean and Paleoproterozoic granitoids of the Carajás metallogenetic province, eastern Amazonian Craton. In: Dall'Agnol R., Rosa-Costa L.T., Klein E.L (eds.). Symposium on magmatism, crustal evolution, and metallogenesis of the Amazonian Craton. Abstracts volume and field trips guide, Belém, PRONEX-UFPA/ SBG-NO, p. 99-150.

Fowler A., Prokoph A., Stern R., Dupuis C. 2002. Organization of oscillatory zoning in zircon: Analysis, scaling geochemistry, and model of a zircon from Kipawa, Quebec, Canada. Geochimica et Cosmochimica Acta, 66:311-328.

Dall'Agnol R. \& Oliveira D.C. 2007. Oxidized, magnetite-series, rapakivitype granites of Carajás, Brazil: Implications for classification and petrogenesis of A-type granites. Lithos, 93:215-233.

Guimarães F.V., Dall'Agnol R., Almeida J.A.C., Oliveira M.A. 2010. Caracterização geológica, petrográfica e geoquímica do Trondhjemito Mogno eTonalito Mariazinha, Terreno Granito-Greenstonemesoarqueano de Rio Maria - SE do Pará. Revista Brasileira de Geociências, 40:196-211.

Hanchar J.M. \& Miller C.F. 1993. Zircon zonation patterns as revealed by cathodoluminescence and backscattered electron images: Implications for interpretation of complex crustal histories. Chemical Geology, 110:1-13.

Heaman L.M., Bowins R., Crocket J. 1990. The chemical composition of igneous zircon suites: Implications for geochemical tracer studies. Geochemical et Cosmochimica Acta, 54:1597-1607.

HancharM.\&HudnickR.L. 1995. The application of cathodoluminescence and back-scattered electron imaging to dating zircons from lower crustal xenoliths. Lithos, 36:289-303.

Horbe M.A. 1998. Petrografia e geoquímica do Granito Pojuca, Serra dos Carajás-PA. Dissertação de Mestrado. Centro de Geociências. Universidade Federal do Pará, Belém, 153 p.

Hoskin P.W.O. \& Ireland T.R. 2000. Rare earth element chemistry of zircon and its use as a provenance indicator. Geology, 28:627-630.

Huhn S.R.B., Santos A.B.S., Amaral A.F., Ledsham E.J., Gouveia J.L., Martins L.B.P., Montalvão R.M.G., Costa V.G. 1988. O terreno granito-greenstone da região de Rio Maria - Sul do Pará. In: SBG, Congresso Brasileiro de Geologia, 35, Belém, Anais 3:1438-1453.

Ishihara S. 1981. The granitoid series and mineralization. Economic Geology, 75:458-484.

Juliani C. \& Fernandes C.M.D. 2010. Well-preserved Late Paleoproterozoic volcanic centers in the São Félix do Xingu region, Amazonian Craton, Brazil. Journal of Volcanology and Geothermal Research, 191:167-179.

Kempe U., Gruner T., Renno A.D., Wolf D., René M. 2004. Discussion on Wang et al. (2000) "Chemistry of Hf-rich zircons from the Laoshan I- and A-type granites, Eastern China". Mineralogical Magazine, 64:867-877.

Krinsley D.H. \& Manley C.R. 1989. Backscattered electron microscopy as an advanced technique in petrography. Journal of Geological Education, 37:202-209. 
Lamarão C.N., Dall'Agnol R., Silva J.S., Soledade G.L. 2010. Morphological and compositional variation in zircons of tinspecialized Paleoproterozoic A-type granites of the Amazonian Craton: Metallogenic implications. In: O. Tapani Ramo, Sari Lukkari, Aku Heinonen (eds.), International Conference on A-type granites and related rocks though time (IGCP-510), Helsinki, Finland. Helsinki University, Department of Geosciences and Geography. Helsinki University Print, Abstract Volume.

Lamarão C.N., Dall'Agnol R., Soledade G.L., Silva J.S. 2007. Variações composicionais de zircão em granitos anorogênicos proterozóicos do Cráton Amazônico: Implicações metalogenéticas. Revista Brasileira de Geociências, 37:693-704.

Lamarão C.N., Pinho S.C.C., Paiva Junior A.L., Toro M.A.G. 2012. Mineralogy and geochemistry of the Paleoproterozoic, tinmineralized Bom Jardim Granite of the Velho Guilherme Suite, eastern Amazonian Craton. Journal of South American Earth Sciences, 38:159-173.

Leite A.A.S., Dall'Agnol R., Macambira M.J.B., Althoff F.J. 2004. Geologia e geocronologia dos granitóides arqueanos da região de Xinguara (PA) e suas implicações na evolução do Terreno GranitoGreenstone de Rio Maria. Revista Brasileira de Geociências, 34:447-458.

Macambira M.J.B. \& Lafon J.M. 1995. Geocronologia da Província Mineral de Carajás: Síntese dos dados e novos desafios. Boletim do Museu Paraense Emílio Goeldi, Série Ciências da Terra, 7:263-287.

Machado N., Lindenmayer Z.G., Krogh T.E., Lindenmayer D. 1991. $\mathrm{U}-\mathrm{Pb}$ geochronology of Archean magmatism and basement reactivation in the Carajás area, Amazon shield, Brazil. Precambrian Research, 49:329-354.

Oliveira M.A., Dall'Agnol R., Althoff F.J., Leite A.A.S. 2009a. Mesoarchean sanukitoid rocks of the Rio Maria Granite-Greenstone Terrane, Amazonian Craton, Brazil. Journal of South American Earth Sciences, 27:146-160.

Oliveira D.C., Dall'Agnol R., Barros C.E.M., Oliveira M.A. 2009b. Geochemistry and magmatic evolution of the Paleoproterozoic, anorogenic A-type Redenção granite of the Jamon Suite, eastern Amazon Craton, Brazil. Canadian Mineralogist, 47:1441-1468.

Owen M.R. 1987. Hafnium content of detrital zircons: A new tool for provenance study. Journal of Sedimentary Petrology, 57:824-830.

Paiva Júnior A.L. 2009. Geologia, petrografia, geocronologia e geoquímica do Granito anorogênico Seringa, Província Mineral de Carajás, SSE do Pará, MS Dissertation, Programa de Pós-graduação em Geologia e Geoquímica, Instituto de Geociências, Universidade Federal do Pará, Belém, 120 p.

Paterson B.A., Stephens W.E., Herd D.A. 1989. Zoning in granitoid accessory minerals as revealed by backscattered electron imagery. Mineralogical Magazine, 53:55-62.

Paterson B.A., Stephens W.E, Rogers G., Williams I.S, Hinton R.W, Herd D.A. 1992. The nature of zircon inheritance in two granite plutons. Transactions of the Royal Society of Edinburgh: Earth Sciences, 83:459-471.

Pinho S.C.C. 2005. Petrografia e geocronologia da borda ENE do Granito Serra da Queimada e da borda SE do Granito Bom Jardim, Província Estanífera do Sul do Pará. Trabalho de Conclusão de Curso, Instituto de Geociências, Universidade Federal do Pará, Belém, 41 p.

Pupin J.P. 2000. Granite genesis related to geodynamics from Hf-Y in zircon. Transactions of the Royal Society of Edinburgh: Earth Sciences, 91:245-256.

Rämö O.T., Dall'Agnol R., Macambira M.J.B., Leite A.A.S., Oliveira D.C. 2002. $1.88 \mathrm{Ga}$ oxidized A-type granites of the Rio Maria region, eastern Amazonian Craton, Brazil: Positively anorogenic! Journal of Geology, 110:603-610

Rios F.J., Villas R.N., Dall'Agnol R. 1995. O granito Serra dos Carajás: 1. Fácies petrográficas e avaliação do potencial metalogenético para estanho no setor norte. Revista Brasileira de Geociências, 25:20-31.

Rios F.J, Villas R.N., Fuzikawa K. 2003. Fluid evolution in the Pedra Preta wolframite ore deposit, Paleoproterozoic Musa granite, eastern Amazonian Craton, Brazil. Journal of South American Earth Sciences, 15:787-802.

Santos J.O.S., Hartmann L A., Gaudette H.E., Groves D.I., McNaughton N.J., Fletcher I.R. 2000. A new understanding of the Provinces of the Amazon Craton based on integration of field and U-Pb and Sm-Nd geochronology. Gondwana Research, 3:453-488.

Souza Z.S., Potrel A., Lafon J.-M., Althoff F.J., Pimentel M.M., Dall'Agnol R., Oliveira C.G. 2001. Nd, Pb and Sr isotopes of the Identidade Belt, an Archean greenstone belt of the Rio Maria region (Carajás Province, Brazil): Implications for the Archaean geodynamic evolution of the Amazonian Craton. Precambrian Research, 109:293-315.

Tassinari C.C.G. \& Macambira M.J.B. 2004. Evolução tectônica do Cráton Amazônico. In: Mantesso-Neto V., Bartorelli A., Carneiro C.D.R. Brito Neves B.B. de. (orgs.) Geologia do Continente Sul Americano: Evolução da obra de F.F.M. de Almeida. São Paulo, Beca, p. 471-486.

Teixeira N.P., Bettencourt J.S., Dall'Agnol R., Moura C.A.V., Fernandes C.M.D., Pinho S.C.C. 2005. Geoquímica dos granitos paleoproterozóicos da Suíte Granítica Velho Guilherme, Província Estanífera do Sul do Pará. Revista Brasileira de Geociências, 35:217-226.

Teixeira N.P., Betencourt J.S., Moura C.A.V., Dall'Agnol R., Macambira E.M.B. 2002. $\mathrm{Pb}-\mathrm{Pb}$ geochronology and $\mathrm{Sm}-\mathrm{Nd}$ isotopic composition of the Velho Guilherme Intrusive Suite and volcanic rocks of the Uatumã Group, south-southeast Pará - Brazil. Precambrian Research, 119:257-275.

Uher P., Breiter K., Klecka M., Pivec E. 1998. Zircon in highly evolved Hercynian Homolka granite, Moldanubian zone, Czech Republic: Indicator of magma source and petrogenesis. Geologica Carpathica, 49:151-160.

Vasquez L.V., Rosa-Costa L.R., Silva C.G., Ricci P.F., Barbosa J.O., Klein E.L., Lopes E.S., Macambira E.B., Chaves C.L., Carvalho J.M., Oliveira J.G., Anjos G.C., Silva H.R. 2008. Geologia e Recursos Minerais do Estado do Pará: Sistema de Informações Geográficas - SIG: Texto explicativo dos mapas Geológico e Tectônico e de Recursos Minerais do Estado do Pará. Organizadores, Vasquez M.L., Rosa-Costa L.T. Escala 1:1.000.000. Belém: CPRM.

Vavra G., Gebauer D., Schmid R., Compston W. 1996. Multiple zircon growth and recrystallization during polyphase Late Carboniferous to Triassic metamorphism in granulites of the Ivrea zone (Southern Alps): An ion microprobe (SHRIMP) study. Contribution to Mineralogy and Petrology, 122:337-358.

Villas R.N.N. 1999. Granito Pojuca, Serra dos Carajás (PA): composição mineralógica, química mineral e controles químicos da alteração hidrotermal. Revista Brasileira de Geociências, 29:393-404

Wang R.C., Fontan F., Xu S.J., Chen X.M., Monchoux P. 1996. Hafnian zircon from the apical part of the Suzhou granite, China. Canadian Mineralogist, 34:1001-1010.

Wang R.C., Zhao G.T., Lu J.J., Chen X.M., Xu S.J., Wang D.Z. 2000. Chemistry of Hf zircons from the Laoshan I- and A-type granites, eastern China. Mineralogical Magazine, 64:867-877.

Arquivo digital disponível on-line no site www.sbgeo.org.br 